\title{
Understanding groundwater - students' pre-conceptions and conceptual change by means of a theory-guided multimedia learning program
}

\author{
Ulrike Unterbruner $^{1}$, Sylke Hilberg ${ }^{2}$, and Iris Schiff ${ }^{1}$ \\ ${ }^{1}$ School of Education, Department of Science Education, University of Salzburg, Salzburg, Austria \\ ${ }^{2}$ Department of Geography and Geology, University of Salzburg, Salzburg, Austria \\ Correspondence to: Ulrike Unterbruner (ulrike.unterbruner@sbg.ac.at)
}

Received: 21 October 2015 - Published in Hydrol. Earth Syst. Sci. Discuss.: 10 November 2015

Revised: 27 April 2016 - Accepted: 28 April 2016 - Published: 10 June 2016

\begin{abstract}
Education on the subject of groundwater is crucial for sustainability. Nevertheless, international studies with students across different age groups have shown that the basic hydrogeological concept of groundwater defined as water within porous and permeable rocks is not an established everyday notion. Drawing from international research, a multimedia learning program Zwischen Regenwolke und Wasserhahn (between the rain cloud and the tap) was developed, which incorporates specific insights from the fields of conceptual change research, multimedia research, and the model of educational reconstruction. The effectiveness of the learning program was ascertained by means of two studies with Austrian seventh grade pupils as well as teacher-training students from the fields of biology and geography in order to ascertain the effectiveness of the learning program. Using a quasi-experimental research design, the participants' conceptions and knowledge of groundwater were determined in a pre- and post-test. The pupils and students greatly benefitted from working through the learning software independently. Their knowledge of groundwater increased significantly compared to the control group and there was a highly significant increase in the number of scientifically correct notions of groundwater. The acceptance of the program was also generally very high. The results indicate that theoryguided multimedia learning programs can play an important role in the transfer of research results to classroom settings, especially in science education.
\end{abstract}

\section{Introduction}

Education on the subject of groundwater is crucial for sustainability. Knowledge about groundwater is an indisputable prerequisite for a sustainable use of water as a valuable natural resource. Reinfried et al. (2012, p. 1365) stressed that "“Water knowledge' has now become a socio-political and future-oriented necessity". This view coincides with that of Dickerson et al. (2007, p. 45), who see knowledge about groundwater as "a fundamental component of scientific literacy", and an indispensable requirement of societal decisionmaking regarding the use and conservation of groundwater. After all, groundwater is one of our most valuable resources and constitutes an essential element that determines our quality of life. On the other hand, however, international studies with students across different age groups have shown that the basic hydrogeological concept of groundwater, which is defined as water within porous and permeable rocks, is not an established everyday notion (see Sect. 2.2.). In order to help (young) people to overcome their obvious difficulties with correctly understanding the concept of groundwater, we developed our interactive multimedia learning program Zwischen Regenwolke und Wasserhahn (between the rain cloud and the tap; Unterbruner and Hilberg, 2012) in a joint effort between the faculties of Geology and Science Education/Biology Didactics at the University of Salzburg. Our aim is to encourage young people to engage with the subject of hydrogeology and to prompt a learning process that will stimulate conceptual change towards a scientifically accurate conception of groundwater. 
We decided to use new media mainly for two reasons: on the one hand, most young people are enthusiastic about new media and enjoy working with multimedia learning programs in class. On the other hand, this allowed us to offer teachers an innovative tool for groundwater education. The program is divided into four chapters ("Water in the ground", "Water in the mountains", "Water in pipes", "Interesting facts about water"). The chapter on "Water in the ground" was the one we tested in our study. Therefore, we will focus on this chapter in our description of the design and our evaluation of the program.

As our target groups, we chose pupils around the age of 13, who are the primary target audience of the multimedia learning program, and teacher-training students, who will have to teach about this topic in the future. Our studies were conducted at Austrian schools and the University of Salzburg. Austrian schools cover geological topics primarily within the scope of the subject of biology and environmental education. Hydrogeology is not explicitly mentioned at any school level since the Austrian curriculum (BMBF, 2000) is kept very general. The curriculum for the seventh grade requires pupils to attain "basic geological knowledge that aids their understanding of the ground, and the interaction between animate and inanimate nature" (BMBF, 2000, p. 4). The precise scope of the subject matter and the time spent on it in order to meet this requirement is left to the teacher's discretion.

In keeping with Thompson et al. (2012), we argue for more educational research to improve student-centered teaching and learning in the fields of earth sciences (see also Seibert et al., 2013). As our theoretical basis, we chose the model of educational reconstruction and conceptual change research. These theoretical frameworks are widely accepted in science education and offer a broad variety of impulses for creating learning environments. Additionally, we included results from multimedia research as an important starting point.

As a first step, we developed a theory-guided multimedia learning program. Subsequently, we analyzed the program's efficiency, in particular in terms of the effectiveness of learning regarding the construction and facilitation of a scientifically correct notion of the groundwater concept.

\section{Theoretical framework}

\subsection{Model of educational reconstruction}

We based our research design on the model of educational reconstruction (MER). The MER was initially developed as a model for instructional planning in school settings and for curriculum development (Kattmann et al., 1997). This model soon proved to be useful in a much wider scope of applications, and became an important framework for research and development in science education (Duit, 2007; Duit et al., 2012; Reinfried et al., 2009). The MER has since been

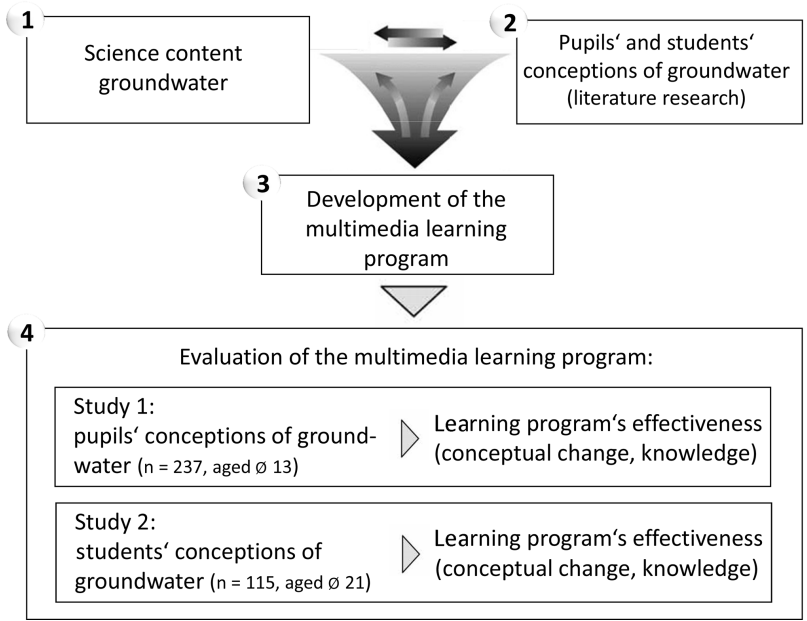

Figure 1. MER-based research design.

adopted as a major theoretical perspective in science education research by various science education groups in Europe.

The MER is based on a constructivist epistemological approach. A balance between science-related and educationoriented issues is considered a necessity for effective teaching and learning. The primary focus of science-related teaching (e.g., in university lectures) tends to be on the scientific nature of a certain topic. Following scientific conventions and routines, generations of teachers used to present scientific content in a simplified (reduced) manner in science instruction, but the MER focusses on a quite different approach: the key message of this model for education-oriented teaching is that a new structure for science instruction has to be found in an iterative process between the analysis of the scientific content and learners' perspectives, preconceptions, and experiences.

The MER integrates three significant components of science education research: (1) the clarification and analysis of scientific content, (2) research on teaching and learning, with a particular emphasis on the role of students' preinstructional conceptions in the learning process, and (3) the design and evaluation of teaching and learning environments (Duit, 2007; Duit et al., 2012). In our study, all three components were applied (see Fig. 1): we took into account the definitions pertaining to the topic of hydrogeology, and the interpretation of the research results regarding pupils' and students' conceptions of groundwater. Based on these, we devised the design of our multimedia learning program. The ascertainment of the effectiveness of our multimedia tool began with an examination of the groundwater concepts of our target groups in order to investigate the extent to which conceptual change and knowledge gain was possible by working through the learning program. 


\subsection{Learners' perspectives on groundwater and conceptual change}

Numerous studies have shown that children come to class with a wide variety of preconceptions in relation to scientific concepts, many of which are inadequate (e.g., Vosniadou, 2013; Hammann and Asshoff, 2014; Kattmann, 2015). Everyday preconceptions are often resistant to change, especially if they appear to be intuitively correct. Because people are familiar with these preconceptions and they have become firmly established in everyday life, they are often considered to be adequate or at least not harmful. Preconceptions or "framework theories" (Vosniadou, 2014) are abstract, naive knowledge structures resulting in deep ontological commitments in terms of how we understand the world. They can impede knowledge restructuring and be resistant to change.

Conceptual change theory is widely accepted in science education, and numerous studies have led to remarkable insights into the thought patterns and conceptions of children and adolescents in various subfields of science. A number of studies show that new information is incorporated into existing ideas for as long as possible and thus retained, even if there are obvious contradictions. Researchers agree that it is one of the most important aims of science instruction to develop students' pre-instructional conceptions towards the intended scientific concepts. Vosniadou (2014) holds that these framework theories do not seem to disappear, but continue to exist and interfere with access to scientific concepts, even among skilled adults. Therefore, from a constructivist point of view, science learning cannot be understood as the replacement of an incorrect by a correct concept (Vosniadou, 2007). Referring to these complex learning processes, Duit and Treagust (2003) and Kattmann (2005) preferred to use the term "conceptual reconstruction" instead of "conceptual change".

With respect to groundwater, research has shown that common conceptions of groundwater are seldom based on scientific findings and that there is a strong prevalence of incorrect hydrogeological concepts. The following represent dominant preconceptions (Dickerson and Dawkins, 2004; Dickerson et al., 2005, 2007; Ben-zvi-Assarf and Orion, 2005; Reinfried, 2005, 2006a, b; Schultz, 2006; Schwartz et al., 2011):

- groundwater is stored in underground lakes;

- groundwater flows in underground rivers, streams, or water veins;

- groundwater accumulates in caves or cavities in the ground.

The ideas that groundwater flows in pipes (Dickerson et al., 2005; Schultz, 2006) or that it is a layer of water at the bottom of water bodies (Reinfried, 2006b) are less common. There is also the representation of groundwater as part of the water cycle, in which the focus is on processes between clouds and the surface of the earth, while those processes that occur within the ground are often disregarded (Shepardson et al., 2009; Reinfried, 2006b).

In their study of 17- and 18-year-olds, Dickerson et al. (2005) asked for an indication of size in order to better classify the conceptions of these adolescents. Over $60 \%$ of respondents imagined groundwater lakes and rivers to be similar to water bodies on the surface of the earth, and to be of considerable size (see also Cheek, 2010).

The idealized notion pertaining to the quality of groundwater is also worth mentioning. Reinfried (2006b) and Reinfried et al. (2012) reported from their research involving 13year-olds, that many of the respondents generally believed that groundwater, and especially spring water, was clean and drinkable. According to Suter et al. (2007), this notion is also shared by adults. There appears to be a lack of awareness concerning threats to groundwater quality and its conservation.

The abovementioned misconceptions of groundwater as an underground lake, river, or accumulation of water in cavities are persistent and outlast academic tuition. Groundwater is an abstract phenomenon that is neither visible nor can it be experienced. It therefore tends to be explained by means of well-known structures and occurrences above the surface of the earth. Aside from this tendency to explain the world by means of analogies, we also often resort to metaphorical explanations. In keeping with the theory of experience-based understanding from Lakoff and Johnson (2003), for example, we frequently refer to water veins in the ground in analogy to the veins transporting blood through our body.

These metaphors and body-related constructions can also be traced throughout historical conceptions of groundwater: as early as 2500 years ago, Pythagoras described the earth as resembling the human body, and Leonardo da Vinci and Johannes Kepler compared the earth's water to the blood of an organism (cf. Reinfried, 2006a, p. 54; 2006b, 40-42). The idea of an underground water network existed up until the mid-19th century (subaerial river model), and it was not until the beginning of the 20th century that the present-day conception was established. In colloquial language, however, millennia-old metaphors persist regardless of modern geological knowledge.

These metaphors are reinforced by mainstream popular science television, literature, and textbooks. Without much reflection on the consequences, some authors display an aquifer in the geologic tradition as a homogenous blue area, which is then interpreted by laypeople in the sense of the abovementioned misconceptions (Schwartz et al., 2011). Inadequate or incorrect visual representations of groundwater in textbooks further impede the development of scientifically accurate concepts. Shepardson et al. (2009) criticized the prevailing misrepresentations of the water cycle in American textbooks, where water is displayed as a stylized landscape with mountains and coastlines. As many pupils are unable to relate these images to their actual surround- 
ings, such representations are impractical for conveying a deeper understanding of the water cycle and the role of groundwater. Reinfried (2006a) also sees pictures in textbooks as a source of misunderstandings. Arrows depicting the groundwater movement from land to sea, for example, could be interpreted by pupils to represent rivers or water veins. Wampler (1998, 2000), Dickerson et al. (2007), and Duffy (2012) also identified illustrations, which are either too simplified or downright negligent. As our recent analysis of 23 textbooks confirms, all of these criticisms can also be applied to Austrian textbooks.

Teachers are not always capable of compensating for the shortcomings of textbooks as their own conception of groundwater is often similar to the preconceptions of their pupils (Dickerson and Dawkin, 2004; Duffy, 2012). In their study conducted as part of the Arizona Water Festival within the scope of a school program in 2009, Schwartz et al. (2011) discovered that pupils performed better when their teachers had taken part in a training workshop on the subject.

\section{How can conceptual change theory benefit teaching about groundwater?}

Strike and Posner (1992) postulated that certain circumstances must be given for conceptual change to take place. The first prerequisite is the existence of a cognitive conflict. Students must become dissatisfied with their own (inadequate) conception and must realize that they are unable to explain a specific phenomenon with sufficient accuracy. Furthermore, new concepts offered to students must be intelligible and plausible, and effectively explain the various phenomena. In accordance with Strike and Posner (1992), Sinatra (2005) also identified message characteristics that can foster or hinder conceptual change: learners must find the message comprehensible, coherent, plausible, and rhetorically compelling.

However, the implementation of research findings in classroom settings often fails to meet expectations (Limón, 2001; Chan et al., 1997; Duffy, 2012). This is partly due to the fact that, in addition to guidance and support from teachers, conceptual change processes demand a higher level of cognitive engagement, motivation, epistemological beliefs, good learning strategies, and beneficial social factors from students than normal classroom instruction, because a cognitive conflict in the absence of knowledge-building activity will not produce conceptual change.

In this sense, Sinatra and Pintrich (2003) and Sinatra (2005) go beyond Strike and Posner's (1992) stringent focus on cognitive processes and depict conceptual change as a complex and dynamic interaction of affective, motivational, and contextual factors. Their focus is on specific conditions of the individual, such as background knowledge, motivation and interests, emotional involvement, self-efficacy, need for cognition, and engagement. Heddy and Sinatra (2013) pointed out that the potential for conceptual change increases with heightened student engagement. As an additional important detail, Sinatra (2005) defined three key aspects of a student's existing background knowledge: (1) the strength of their preconceptions - the stronger the ideas, the more connected they are in their brain and the less likely they are to change; (2) coherence - less coherent ideas are more susceptible to change; and (3) commitment - ideas an individual is strongly committed to are less likely to change.

Returning to the topic of groundwater, we can assume that a learning program, which aims to give children, adolescents, or adults a scientifically accurate understanding of groundwater, must take into account existing preconceptions. In the words of Sinatra (2005), students' preconceptions of underground lakes, rivers, and water-filled caves are likely to be "strong ideas" - not least because they have existed for centuries - while coherence and commitment to the topic of groundwater are probably relatively weak. In Austria, groundwater awareness is not particularly widespread, nor does there seem to be much motivation for or commitment to engaging with the topic. As groundwater availability is generally given, Austrian adolescents do not give much thought or attach great importance to it. Referring to Sinatra's categories, their commitment can be expected to be low. With the use of new media in hydrogeology education, however, a higher level of motivation and engagement can be expected.

In the following sections, we present the underlying deliberations for the theory-guided design of the multimedia program.

\section{Theory-guided designing of the multimedia learning program}

\subsection{What adolescents need to understand about groundwater}

The multimedia learning software deals with various questions concerning groundwater in unconsolidated rocks where it occurs in the pores between the mineral grains. In order to develop an adequate model of groundwater (cf. Hölting and Coldewey, 2013; Davis and de Wiest, 1966; Hilberg, 2015), adolescents need to understand the following:

- Rainwater seeps into the ground through cavities between mineral grains, and accumulates in permeable and porous sediments above an impermeable layer. The characteristics of the pore space, and therefore its suitability as a groundwater aquifer, depend on the grain size. Larger grains constitute larger pore spaces while smaller grains are surrounded by smaller pore spaces. It generally applies that the more pore space available, the more groundwater can be transported and stored therein. Very small grain sizes (silt and clay) constitute pore spaces that are too small to allow water to percolate and hence form an aquiclude. 
- Groundwater flows within the pore spaces.

- Below a certain depth, which can be a few decimeters or a few hundred meters below the surface, and depending on annual rainfall and the location of the surface water, the pores between the grains are entirely filled with water (aquifer).

- The groundwater surface is the boundary between the unsaturated zone (ground air) and the aquifer, which is not in a fixed position but fluctuates depending on the influx into and discharge out of the aquifer.

- Wells are used for extracting groundwater.

- Pollutants, e.g., from unsecured waste sites and agriculture, can contaminate groundwater.

- Groundwater needs to be protected from such contamination.

\subsection{General design of the learning program based on multimedia research}

Theories of multimedia learning (Mayer, 2009; Moreno, 2006) constitute an important basis for designing such a learning program. One of their key messages is that meaningful learning can be promoted by taking into account the architecture of human information processing and the characteristics of the working memory. Mayer $(2005,2009)$ and Mayer and Moreno (2003) recommended several principles of multimedia learning, which we adopted when designing our multimedia learning program: we implemented a good balance between auditory and visual presentations of information. The texts are kept short (no scrolling) and the criteria for comprehensibility according to Langer et al. (2011) were taken into consideration in the text presentation. With regard to motivation, a geologist guides the user through the program in the role of a "pedagogical agent" (Mayer, 2005). She offers explanations, asks questions, and gives instructions for the interactive tasks as well as feedback on the test questions.

Experiences and results of studies with other multimedia learning programs on biological topics were also taken into consideration (Unterbruner and Unterbruner, 2002, 2005; Unterbruner et al., 2008). The learning program is characterized by a clear structure and a row of information units followed by test questions. Three test questions conclude each thematic sub-unit and are designed to give users feedback on how well they have grasped the learning contents, and to fuel their motivation. Working through a chapter takes between 15 and $20 \mathrm{~min}$.

The program is interactive, cognitively activating, and devised to be worked through independently. Cognitive activation is to be achieved by means of a problem-oriented approach on the one hand (e.g., Unterbruner and Pfligersdorffer, 2007; Zumbach et al., 2014), and through interactive elements on the other. Various interactive elements require the user's active participation, for example by using a magnifying glass to enlarge smaller details.

\subsection{The storyboard's dramaturgy of "Water in the ground"}

In accordance with the iterative approach of MER, we based our theoretical considerations regarding the design of the multimedia learning program on the investigations about students' pre-conceptions by Dickerson and Dawkins (2004), Dickerson et al. (2005, 2007), Ben-zviAssarf and Orion (2005), Reinfried (2005, 2006a, b), Shepardson et al. (2009), Schultz (2006), and Schwartz et al. (2011) on the one hand, and on basic hydrogeological concepts on the other. In the latter case, we focussed on the most relevant scientific aspects to our target group of young people, who may never have dealt with the topic of groundwater before. Accordingly, results from conceptual change research by Strike and Posner (1992), Vosniadou (2007), and Sinatra (2005) broadly influenced our storyboard design. The dramaturgy of the multimedia program/storyboard will be described in detail below (see Table 1).

First of all, we decided not to start our program by activating preconceptions and previous knowledge in order to avoid reinforcing existing misconceptions (cf. Sinatra, 2005). As a primary problem, we identified that most people have no concrete notion or, at best, a very vague idea of the structure and composition of the ground (i.e., weak coherence; cf. Sinatra, 2005). Groundwater may be an abstract phenomenon, but contrary to the issue of climate change, it can sometimes become quite tangible (e.g., in building trenches). However, we assume that most people do not make the connection between the observation of these phenomena and groundwater. Our primary aim, i.e., to convey an accurate understanding of groundwater, thus requires the best possible visualization of the composition of the "ground beneath our feet". Therefore, the program begins with conveying said knowledge, but without making any direct reference to groundwater at first. The subject of groundwater is subsequently developed based on that knowledge. We accordingly developed a dramaturgy for the storyboard based on the following central questions (cf. Hilberg, 2015):

1. What makes up the ground beneath our feet?

2. What causes the layers in the ground?

3. How can I envision groundwater?

4. How does rain become groundwater?

5. Why do I need to know about groundwater?

In the following, main details of the storyboard are explained.

\subsubsection{What makes up the ground beneath our feet?}

The challenge-oriented question of what makes up the ground beneath our feet is intended to arouse the user's cu- 
Table 1. Key questions in the designing process with regard to groundwater (GW) preconceptions (as far as reported in literature), scientific conceptions, and multimedia implementation.

\begin{tabular}{|c|c|c|c|}
\hline Key questions & Students' preconceptions & Scientific conceptions & Storyboard/multimedia designing \\
\hline $\begin{array}{l}\text { What makes up } \\
\text { the ground } \\
\text { beneath our feet? }\end{array}$ & Not reported in literature & $\begin{array}{l}\text { Layers consisting of rock material of various grain } \\
\text { sizes (gravel, sand, or clay) as result of erosion and } \\
\text { sedimentation processes }\end{array}$ & $\begin{array}{l}\text { Animation: virtual elevator; } \\
\text { pictures of a drill hole; virtual examination of a drill } \\
\text { core consisting of gravel, sand, and clay } \\
\text { Interactive presentation: soil profile; } \\
\text { presentation and explanation of the scientific model } \\
\text { (Ecovia) }\end{array}$ \\
\hline $\begin{array}{l}\text { What causes the } \\
\text { layers in the } \\
\text { ground? }\end{array}$ & Not reported in literature & $\begin{array}{l}\text { Transport and sedimentation of rock material } \\
\text { driven by surface runoff; } \\
\text { flow velocity controls transport capacity and thus } \\
\text { grain-size distribution of the sediments }\end{array}$ & Interactive example of an alpine river \\
\hline $\begin{array}{l}\text { How can I } \\
\text { envision } \\
\text { groundwater? }\end{array}$ & $\begin{array}{l}\text { GW as subterranean rivers, } \\
\text { water veins, or lakes; } \\
\text { water stored in caves or } \\
\text { cavities in the ground }\end{array}$ & $\begin{array}{l}\text { GW fills and flows through pores between distinct } \\
\text { grains of a coarse-grained sedimentary layer } \\
\text { (aquifer); } \\
\text { aquifer is limited by fine-grained impermeable } \\
\text { sediments or hard rocks (aquiclude) }\end{array}$ & $\begin{array}{l}\text { Presentation of resp. confrontation with the } \\
\text { scientifically correct conception of GW and the three } \\
\text { most common misconceptions (subterranean rivers, } \\
\text { lakes; caves) }\end{array}$ \\
\hline $\begin{array}{l}\text { Why do I need to } \\
\text { know about } \\
\text { groundwater? }\end{array}$ & Not reported in literature & $\begin{array}{l}\text { GW resources can be influenced by many } \\
\text { activities of daily life; GW protection and } \\
\text { sustainable use requires a fundamental understanding of } \\
\text { hydrogeological processes }\end{array}$ & $\begin{array}{l}\text { Application task: well drilling; } \\
\text { case study about risks of contamination by } \\
\text { deposition of refuse } \\
\text { Animation: path of hazardous substances in the } \\
\text { ground and consequences }\end{array}$ \\
\hline
\end{tabular}

riosity. Showing a picture of people standing in the pouring rain, the geologist explains that between 10 and 80 out of every 100 raindrops seep into the ground. But where do they end up? To visualize this, she invites the user on a virtual elevator ride into the ground.

A virtual elevator (Fig. 11, screenshot 1) then takes the user into the ground beneath our feet. It makes several stops at different levels and information is provided as to what exactly can be expected at different depths in the ground: at $2 \mathrm{~m}$, we see the pipelines of the sewerage system. At $3 \mathrm{~m}$, there is coarse gravel. At $10 \mathrm{~m}$, we find ourselves in an underground train station. At $11 \mathrm{~m}$ below the surface, the elevator passes through fine-grained gravel. At $14 \mathrm{~m}$, we encounter sand and, finally, at $18 \mathrm{~m}$ below the surface, we arrive at groundwater level. Further down, at $25 \mathrm{~m}$, the elevator passes through finegrained wet gravel and at $30 \mathrm{~m}$ the elevator ride ends in dry clay.

How geologists obtain their knowledge about the subsurface is shown in the following section: pictures of a drill hole are presented and a drill core consisting of gravel, sand, and clay can be examined with a magnifying glass. Two further drill cores as well as the corresponding soil profiles are also shown. The geologist then presents a scientific model developed by Ecovia for the procurement of hydrogeological data. Gravel, sand, and clay are layered between acrylic glass panes. The water level, the flow of the groundwater, and the ingress of pollutants can be freely adjusted and monitored in transparent tubes. This model is referred to a number of times thereafter and is used to illustrate various pieces of information. All animations are programmed based on the layers in the model (Fig. 11, see screenshots 1, 2, 4, and 5). Based on the recommendations of Dickerson et al. (2005), the spatial dimensions under consideration are explicitly addressed. Houses are shown after presenting the model in order to illustrate the magnitude of the subsurface layers displayed, and the distance traveled by the virtual elevator is also indicated (see red figure in Fig. 11, screenshot 2).

\subsubsection{What causes the layers in the ground?}

What processes lead to the formation of underground layers and how historical information regarding their formation can be deduced based on the sequence of layers, are the topics of the interactive section that follows. The formation of the subsurface layers is demonstrated based on a concrete example of an alpine river. Information can be obtained by hovering over the individual sections with the mouse.

\subsubsection{How can I envision groundwater?}

Following appropriate elaboration on the geo-scientific concept of sediments, the topic of groundwater is introduced. Four people explain how they envision groundwater. Besides the technically correct definition of "water that flows between gravel and sand grains", the three most common notions of groundwater are presented (underground lake, river/water veins, water in caves). The user is prompted to 
choose which statement he/she considers to be correct, followed by feedback on each of the opinions provided by the geologist.

The aim is to activate the user's prior knowledge about groundwater, and to make clear that there might be a discrepancy between their own pre-conceptions and the content being presented (cf. cognitive conflict). This seeks to emphasize that there are various notions related to concept of groundwater and that not all of them are technically correct. But in order to avoid reinforcing pre-existing misconceptions, the options presented are briefly commented on (e.g., "an underground lake does not exist"). In accordance with Sinatra (2005), who holds that strong ideas are rather resistant to change, we aimed to avoid a possible emphasis or even consolidation of these inadequate conceptions. Instead, we purposefully steer the user's attention toward the scientifically correct definition, and rather than repeating the misconceptions, the geologist asks how the pore space between the grains becomes filled with water.

\subsubsection{How does rain become groundwater?}

In a next step, it is illustrated by means of an experimental demonstration showing the permeability of gravel, sand, and clay how rain turns into groundwater (Fig. 11, screenshot 3 ). The user is prompted to guess through which of the three sediments the water will percolate the fastest. In order to promote cognitive activation, the answer he/she chooses is not commented on immediately, but the correct answer is given in the form of individual feedback following the demonstration.

Now the hydrogeological terms of pore space and aquiclude are explained. We consider an accurate understanding of the concept of pore space as a crucial prerequisite for the consolidation of a geo-scientific concept of groundwater. An animation, which can be repeated, shows a raindrop on its way through the layers of the model. In the first run-through, the user is given a concrete demonstration. Subsequently, he/she is provided with explanations regarding the flow rate through each of the different substrates (Fig. 11, screenshot 4).

Following this detailed presentation, the overall model is shown again and the geologist simulates rain using bluecolored water. Subsequently, the flow of groundwater, the interaction between rivers and groundwater, and the terms of groundwater table and aquifer are exemplified by means of the Ecovia model.

By this point in the learning program, we have portrayed the hydrogeological basics in an interactive and cognitively activating manner. We have ensured that the scientifically accurate conception is communicated in an "intelligible and plausible" way (Strike and Posner, 1992).

\subsubsection{Why do I need to know about groundwater?}

The aim of the last part is to demonstrate how the new conception can be fruitful. This is achieved by addressing the topics of groundwater use, the threats groundwater is exposed to, and the protection and conservation of groundwater.

Referring back to the model once again, the user is asked where wells could be drilled. The user must place small drilling rig icons and receives feedback as to whether or not the structure of the layered subsurface is suitable at the chosen position. The user is then confronted with a case study in which the mayor of a town receives a proposal to use a plot of land as a refuse disposal site. An animation shows the path hazardous substances would take through the ground in red, illustrating whether they would potentially pose a threat to the quality of an existing well (Fig. 11, screenshot 5). Finally, the threat of groundwater pollution by the agricultural sector is addressed.

Figure 11, screenshot 6 , shows one of the eight exercises/test questions to be completed in this chapter.

\section{Research questions}

We aimed to address the following key research questions:

- Which pre-instructional conceptions do pupils and students have regarding groundwater?

- Does conceptual change occur as a result of working with the multimedia learning program?

- Does knowledge about groundwater increase by using the learning program?

- What is the participants' level of acceptance of the multimedia learning program?

\section{Sample}

Pupils/school: this sample consisted of 237 Austrian seventh grade pupils $\left(n_{\text {female }}=99, n_{\text {male }}=138\right)$ between the ages of 12 and $14(M=12.48$; SD (standard deviation) $=0.62$ ), attending a secondary school (Gymnasium and Neue Mittelschule). The group was made up of pupils from 12 different classes across four schools. The pupils from nine of those classes were assigned to the experimental group $(n=177)$ and those from three classes were assigned to the control group $(n=60)$. According to their teachers, none of the participating classes had previously been taught about groundwater and hydrogeological issues. The level of knowledge on the topic of groundwater as provided for by the Austrian curriculum is limited. 
Table 2. Research plan (EG is the experimental group, CG the control group, T1 the pre-test, T2 the formative evaluation, T3 the post-test).

\begin{tabular}{lccccc}
\hline \multirow{2}{*}{ Group } & & Phase 1 & \multicolumn{2}{c}{ Phase 2 } & Phase 3 \\
\cline { 4 - 5 } & & Start & 3 weeks later & $\begin{array}{c}\text { Immediately after } \\
\text { learning program }\end{array}$ & $\begin{array}{c}\text { 2 weeks after } \\
\text { learning program }\end{array}$ \\
\hline \multirow{2}{*}{ Pupils } & EG & T1 & Learning program & T2 & T3 \\
& CG & T1 & - & - & T3 \\
\hline \multirow{2}{*}{ Students } & EG & T1 & Learning program & T2 & T3 \\
& CG & T1 & - & - & T3 \\
\hline
\end{tabular}

Students/university: this sample consisted of 115 Austrian teacher-training students in the subjects of biology and environmental education and geography and economics in the first stage of their degree at the University of Salzburg. In all, 73 students were assigned to the experimental group and 42 students to the control group. The percentage of female students $(70 \%)$ was considerably higher than that of male students, which is consistent with the general gender distribution in these two fields of study. The average age was 21.4 years $(\mathrm{SD}=3.99)$. All of these students had received their high school qualification at a higher secondary school. Since higher secondary schools do not explicitly cover the topic of hydrogeology in the curriculum, it can be assumed that their academic tuition on this subject matter was likely to be marginal. Based on their choice of further education, however, it can be assumed that this group possesses a particular interest in biology and/or geoscience.

\section{Methodology}

The quasi-experimental design of our research regarding the effectiveness of the multimedia learning program consisted of a pre-test and a post-test to evaluate preconceptions, knowledge, and attitudes regarding groundwater, as well as individual processes of working through the program, and a questionnaire for its formative evaluation (see questionnaires in the Supplement). In order to control repeat measurement effects and to exclude random events (e.g., TV documentaries) from impacting our results, participants from each sample (pupils and students) were randomly assigned to an experimental or control group (see Table 2). The control group did not work on groundwater, because we did not intend to compare different teaching methods or media with the multimedia learning program, but to investigate the program's learning efficacy.

The teaching staff of the schools and university provided time for the participants to complete the pre- and post-tests (T1 and T3), and to work through the program (including T2) (see Table 2). The participating pupils and students were thus in their familiar educational environment, and were motivated to engage in a scientific research study. The multimedia learning program was not implemented in class. The participants worked through the program individually (using headphones) and at their own pace.

By agreement with the teaching staff, no other work on the topic of groundwater was carried out during the investigation period. The post-test was, therefore, no examination (in a school or university context), in which case the pupils/students could have been expected to engage with the topic individually in order to receive a good grade. In order to ascertain long-term - as opposed to short-term - knowledge acquisition, the post-test was conducted 2 weeks after the participants had worked through the program.

\subsection{Instruments}

\subsubsection{Pre- and post-test (T1, T3)}

The questionnaire served the purpose of data collection pertaining to

1. pre- and post-instructional conceptions of groundwater;

2. knowledge about hydrogeological issues.

\subsubsection{Pre- and post-instructional conceptions of groundwater}

Since drawing is an effective method to capture mental representations (cf. Schwartz et al., 2011, p. 148; Dove et al., 1999; White and Gunstone, 1992), the participants were asked to draw how they envisioned groundwater. They were also asked to verbalize (open question) their perceptions of groundwater. The wording of the question and instructions for the drawing was kept very broad in order to avoid influencing the outcome to the greatest possible extent.

The drawings from the pre- and post-tests (T1, T3) were analyzed and double coded by experts (science education, geology; excellent inter-rater reliability) (Cohen's kappa for students: $k=0.91$, for pupils: $k=0.86$; cf. Fleiss and Cohen, 1973) based on the following categories:

Hydrogeologically correct conception:

- water in porous and permeable rocks (Fig. 2);

- partially correct: water in porous and permeable rocks, but with an important detail, e.g., the aquiclude, missing (Fig. 3). 
(a)

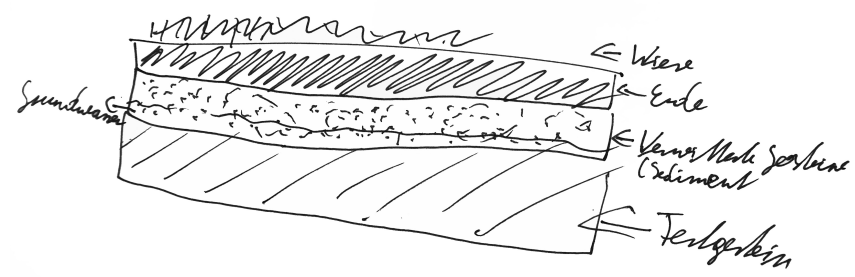

(b)

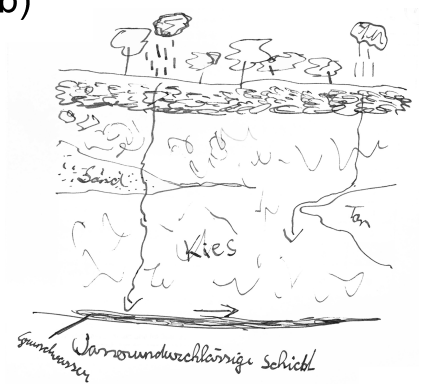

Figure 2. Examples for the categories of analysis. Geologically correct drawings (b student; a pupil). Wiese (grasland), Erde (soil), Festgestein (hard rocks), Grundwasser (groundwater), wasserundurchlässige Schicht (unpermeable layer), Kies (gravel) Ton (clay).

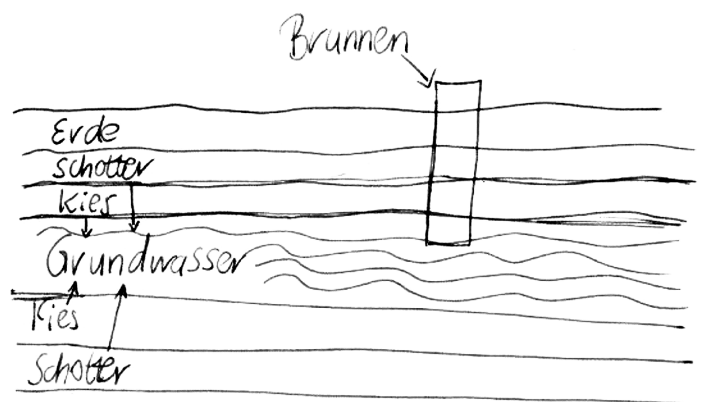

Figure 3. Examples for the categories of analysis. Partially correct representation: the arrows express that the part marked with Grundwasser (i.e., groundwater) also contains broken stones and gravel; but the aquiclude is missing. Schotter (gravel), Brunnen (well); see caption of Fig. 2 for further translations.

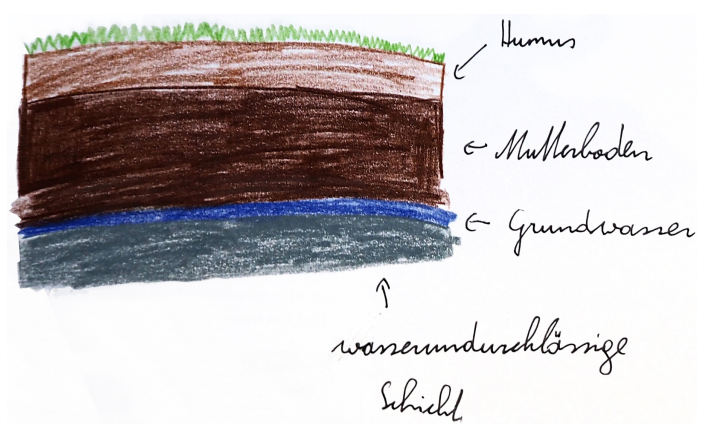

Figure 4. Examples for the categories of analysis. Groundwater as a subterranean river. Mutterboden (soil); see caption of Fig. 2 for further translations.

Hydrogeologically inadequate conceptions:

- groundwater as a subterranean river, stream, or water vein (Fig. 4);

- groundwater as a subterranean lake (Fig. 5);

- groundwater stored in caves or cavities in the ground (Fig. 6);

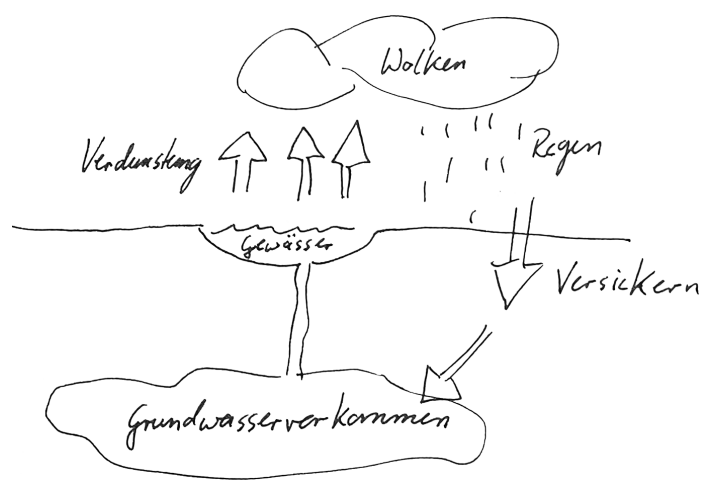

Figure 5. Examples for the categories of analysis. Groundwater as a subterranean lake. Wolken (clouds), Verdunstung(evaporation), Regen (rain). Gewässer(surface water body), versickern (percolate).

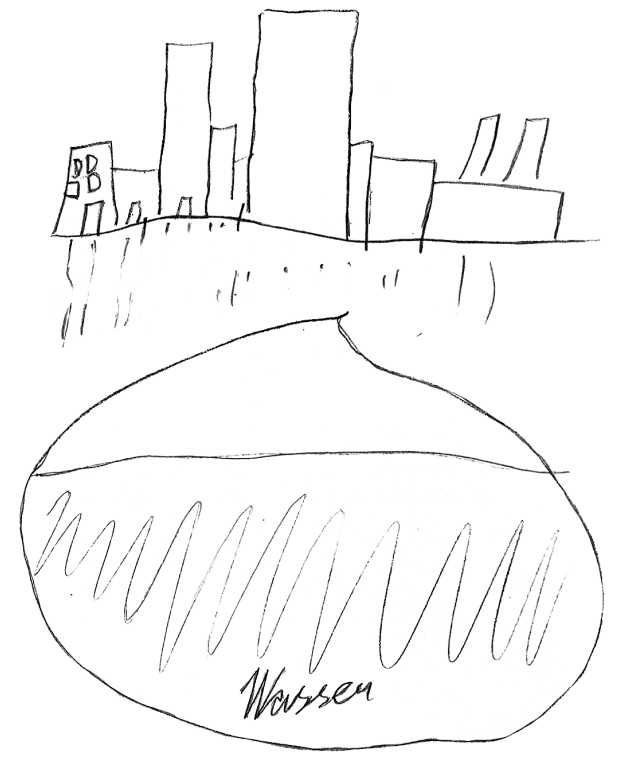

Figure 6. Examples for the categories of analysis. Groundwater in holes or caverns. 
Table 3. Comparison of the conceptions of groundwater of pupils and students from the experimental group in the pre- and post-tests (in \%).

\begin{tabular}{lrrrrr}
\hline & \multicolumn{2}{c}{ Pupils $(n=177)$} & & \multicolumn{2}{c}{ Students $(n=73)$} \\
\cline { 2 - 3 } \cline { 6 - 6 } & Pre-test & Post-test & & Pre-test & Post-test \\
\hline Correct conception & 3.4 & 30.4 & & 11.3 & 43.6 \\
Partially correct & 5.7 & 11.8 & & 8.5 & 5.6 \\
GW as subterranean river & 46.7 & 33.3 & & 29.6 & 15.5 \\
GW as subterranean lake & 15.1 & 10.6 & & 31.0 & 11.3 \\
GW in caves & 6.7 & 1.7 & & 0.0 & 1.4 \\
Water cycle & 1.1 & 0.6 & & 4.2 & 0.0 \\
Surface water & 8.3 & 1.7 & & 0.0 & 0.0 \\
Water pipes & 5.5 & 1.1 & & 1.4 & 1.4 \\
Other conceptions & 5.0 & 2.8 & & 8.5 & 8.5 \\
Unclear drawings & 2.5 & 6.0 & & 5.7 & 12.7 \\
\hline
\end{tabular}

- groundwater as part of the water cycle;

- groundwater as water at the bottom of water bodies;

- other conceptions such as surface waters, water in pipes;

- vague drawings.

The answers to the open question regarding the participants' conceptions of groundwater were analyzed for accuracy and level of detail - ranging from very broad (e.g., "Water in the ground") to specific and with the mention of various details (e.g., rainwater percolates into the ground, seeps through the soil, and is collected above an impervious layer).

\subsubsection{Knowledge about hydrogeological issues}

The questionnaire in the pre- and post-test (T1, T3) contained 16 items pertaining to the geological concepts relevant to the understanding of groundwater, namely sediments, porosity, flow of groundwater, groundwater surface, aquifer, and aquiclude. Furthermore, a question regarding the use of groundwater, and a transfer task with a narrative example of the agricultural use of fertilizer and its potential threat for groundwater were posed. The wording of these items was closely related to the contents of the program, and the items were identical, but the language was adapted accordingly for pupils and students.

Three questions were open while the rest were multiplechoice questions or statements that had to be classified as either being correct or incorrect. The multiple-choice questions were supplemented by a scale from 1 to 10 , on which the participants had to indicate how sure they were about their answers. The aim was to evaluate whether the answers given were merely a guess (low score) or whether, according to the participants' subjective opinion, they were confident about their knowledge. By this means, an increase in knowledge could be determined when correct answers were given in both the pre- and post-test, but the subjective confidence rating had increased significantly.

\subsubsection{Questionnaire for formative evaluation}

The participants were given a questionnaire (T2) and asked to evaluate the program immediately after working through it. They were instructed to rate it on an 18-item Likert scale to evaluate the degree of usability, the subjective success rate, the enjoyment, as well as how understandable and interesting they perceived the program to be. The internal consistency of the evaluation questionnaire, measured by means of Cronbach's Alpha, was given in both groups with values of $\alpha=0.81$ (pupils) and $\alpha=0.74$ (students).

All data were analyzed using IBM SPSS 22.0.

\section{Results}

\subsection{Pre-instructional conceptions of groundwater}

In line with the international studies described above, the results of the drawing exercises from the pre-test showed that the dominating preconceptions of students and pupils were the academically incorrect conceptions of an underground river (students: $30 \%$, pupils: $47 \%$ ) and an underground lake (students: $31 \%$; pupils: $15 \%$ ). Other concepts were rarely mentioned. The scientifically accurate conception of water within porous and permeable rocks was drawn by $11 \%$ of students, and only $3 \%$ of pupils (see Table 3 ).

In their verbal descriptions, $60 \%$ of pupils vs. $89 \%$ of students described the concept correctly. This discrepancy can be attributed to the fact that most of the verbal descriptions of groundwater provided were very short and generic (e.g., "Water in the ground"), and did not express nor allow conclusions as to the underlying conceptions.

\subsection{Conceptual change}

The scientifically adequate concept of groundwater was significantly more prevalent in the post-test. The percentage of correct and partially correct drawings rose from 9 to $42 \%$ for pupils and from 20 to $49 \%$ for the students. The evaluation of the graphical representations produced by the participants showed a statistically highly significant shift from inadequate preconceptions to the correct conception. An evaluation of the verbal descriptions of groundwater yielded similar results, although from a much higher baseline (Fig. 7, see also Table 3).

When examining the preconceptions of the underground river and lake in detail, the Wilcoxon test showed that these perceptions were significantly reduced in the post-tests for both pupils and students (Fig. 8).

The degree to which this effect can be attributed to the effectiveness of the multimedia learning program becomes evident in a comparison of the experimental and control groups. The concept scores (i.e., sum of points achieved in the concept tasks, max. 4) of the pre- and post-tests of both groups were calculated and analyzed. This showed a significant im- 

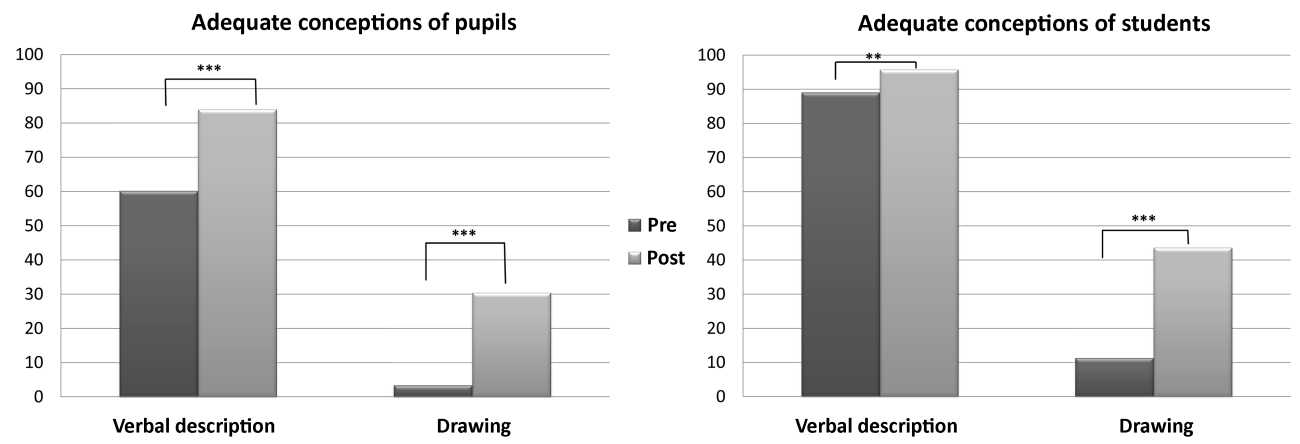

Figure 7. Scientifically accurate conceptions of pupils and students from the experimental group in the pre- and post-test.

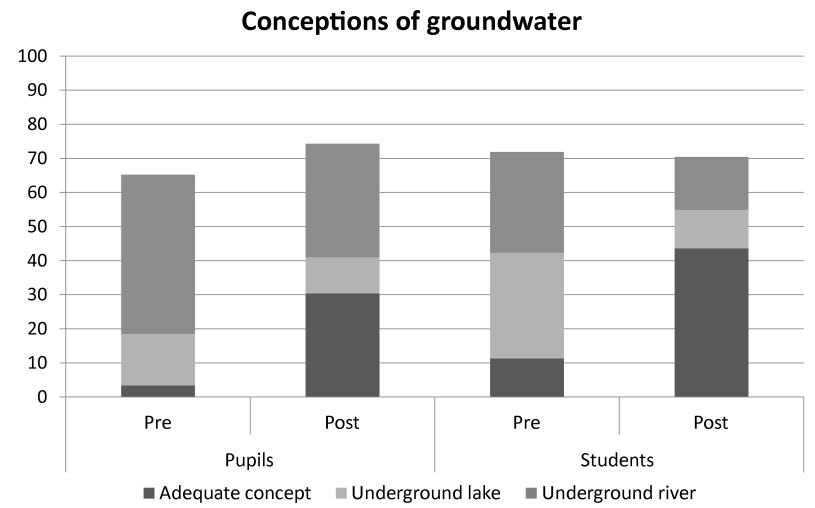

Figure 8. Comparison of the correct and most frequently mentioned incorrect groundwater conceptions of pupils and students from the experimental group in the pre- and post-tests.

provement in the scores of the participants from the experimental group while the scores of the control group saw a slight decrease (pupils - experimental group: +1.20 points, control group: -0.03 points; students - experimental group: +1.27 points, control group: -0.07 points) (Fig. 9)

\subsection{Knowledge acquisition}

In order to verify the overall increase in knowledge, all items testing knowledge were combined to a total knowledge score. Every correct answer was worth 2 points, resulting in a maximum total knowledge score of 24 points in both the preand the post-test. The overall increase in knowledge (or decrease, as the case may be) was determined by the difference between the total knowledge scores from the pre- and posttest.

A comparison with the control group was once again used to show that the increase in knowledge was, in fact, attributable to the use of the multimedia learning program. On average, the scores of students from the experimental group increased by 3.29 points while those students from the control group only achieved an increase by 0.89 points. The ANOVA revealed a highly significant dif- ference between the two groups $(F(1,86)=12.35 ; p<0.01$; $\eta^{2}=0.13$ ). In the case of the pupils, the experimental group achieved an increase by 5.31 points compared to 3.82 points $\left(F(1,120)=5.88 ; p<0.05 ; \eta^{2}=0.05\right)$ in the control group.

Regarding the fundamental geological concepts of porosity and sediments, the increase in knowledge was shown to be particularly high in both experimental groups. Pupils and students performed best in regards to sediments, flow rates in gravel, sand, and clay and in depicting the groundwater surface.

The ANOVA also showed that the participants in the experimental group were significantly more confident in their answers in the post-test compared to the participants of the control group.

We also examined whether the increase in knowledge varied between participants with a higher level of prior knowledge compared to those with little or no prior knowledge. In the experimental groups of both pupils and students, we observed that participants with little prior knowledge achieved an increase in their knowledge scores in a significantly greater number of instances than those who possessed a higher level of prior knowledge to begin with.

\subsection{Acceptance of the learning program}

The multimedia learning program was evaluated very positively. From a maximum of 60 possible points (4 points per item) in the evaluation questionnaire, the average score given by pupils was 51.4 points $(s=5.47)$ while students gave an average of 55 points $(s=3.87)$.

The results of the individual scales related to interest, comprehensibility, enjoyment, subjective achievement, and usability are summarized in Table 4.

\section{Discussion and conclusions}

Even though the importance of groundwater to humans and nature cannot be overstated, the results of our studies show that young people often lack a correct understanding of this topic. In alignment with international studies, most of 

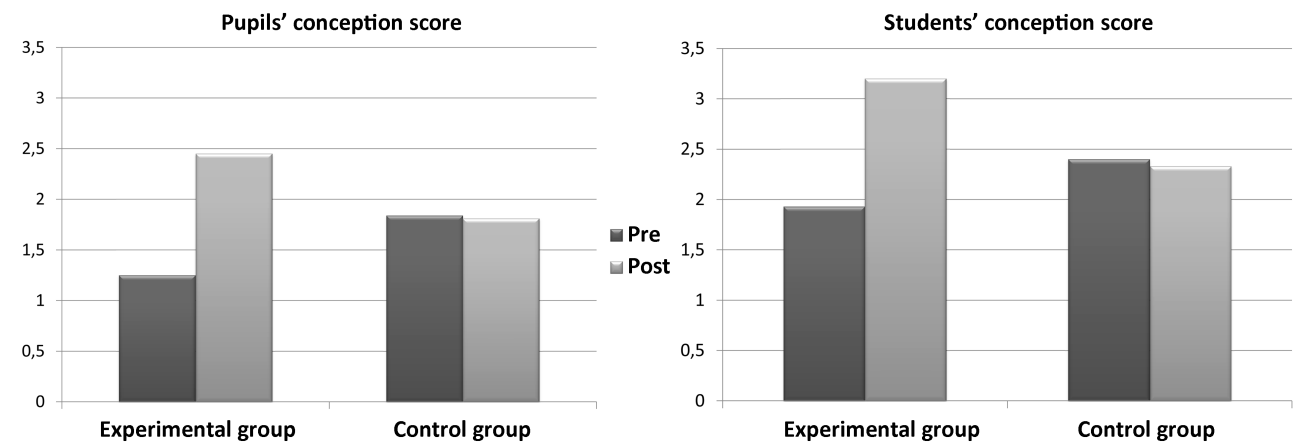

Figure 9. Comparison of the conception scores of the experimental and control groups $\left(n_{\text {pupils }}=195 ; n_{\text {students }}=92 ;\right.$ max. 4 points $)$.

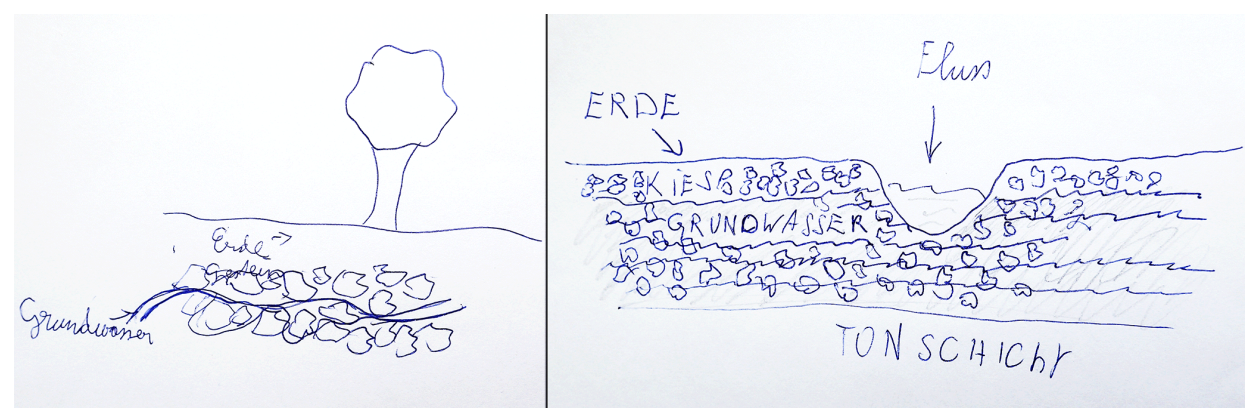

Figure 10. Example of conceptual change in a 13-year-old boy from learning with the multimedia program. Left panel: pre-test, right panel: post-test Erde (soil), Kies (gravel), Fluss (river), Tonschicht (clay layer), Grundwasser (groundwater). Left panel: pre-test, right panel: post-test Erde (soil), Kies (gravel), Fluss (river), Tonschicht (clay layer), Grundwasser (groundwater).

Table 4. Results of the formative evaluation (Likert-scale from $1=$ strongly disagree to $4=$ strongly agree).

\begin{tabular}{lccccc}
\hline & \multicolumn{2}{c}{ Pupils } & & \multicolumn{2}{c}{ Students } \\
\cline { 2 - 3 } \cline { 5 - 6 } & $x$ & SD & & $x$ & SD \\
\hline Interest & 3.74 & 0.33 & & 3.36 & 0.48 \\
Comprehensibility & 3.74 & 0.29 & & 3.49 & 0.38 \\
Enjoyment & 3.42 & 0.68 & & 3.20 & 0.77 \\
Subjective achievement & 3.61 & 0.43 & & 3.50 & 0.47 \\
Usability & 3.28 & 0.73 & & 3.29 & 0.79 \\
\hline
\end{tabular}

the Austrian pupils and students from our pre-test imagined groundwater to be a subterranean river or lake. Only $3 \%$ of the 13 -year-olds and $11 \%$ of the university students tested produced drawings that could be considered an expression of a correct understanding of groundwater in porous and permeable rocks. These results highlight the importance of teaching about groundwater within the scope of science education and education for sustainable development.

We have demonstrated that groundwater education can be significantly improved by using our multimedia learning program. Both pupils and students achieved a significant increase in correct groundwater conceptions and knowledge during a single session with the multimedia program (15 to
$20 \mathrm{~min}$ ), and without any accompanying instruction in class or as part of a university course. These results indicate that our didactic concept with reference to conceptual change research is useful in order to promote learning about groundwater.

As an example of successful learning with the multimedia learning program, the results of a 13-year-old boy regarding conceptual change and knowledge increase are shown in Fig. 10. In the pre-test, he had imagined groundwater to be a subterranean river; 2 weeks after working with the multimedia learning program, his drawing looked quite different. He produced a hydrogeologically correct drawing of groundwater with porous and permeable sediment layers, clay as an aquiclude, and a correct water table, even including the profile of an aerial river. The considerable refinement in his understanding of the concept of groundwater was also obvious in his retention performance. In the pre-test, he had answered 9 out of 16 questions correctly, compared to 15 out of 16 in the post-test. His subjective confidence rating had increased significantly (mean values on a 10-point scale: pretest $6.4 \rightarrow$ post-test 9.8 ).

In a similar way, $42 \%$ of pupils and $49 \%$ of students in the experimental group drew a correct or partially correct representation of the concept of groundwater in the post-test as opposed to the pre-test, in which a mere 9 and $20 \%$, respectively, demonstrated a correct understanding. Highly signifi- 


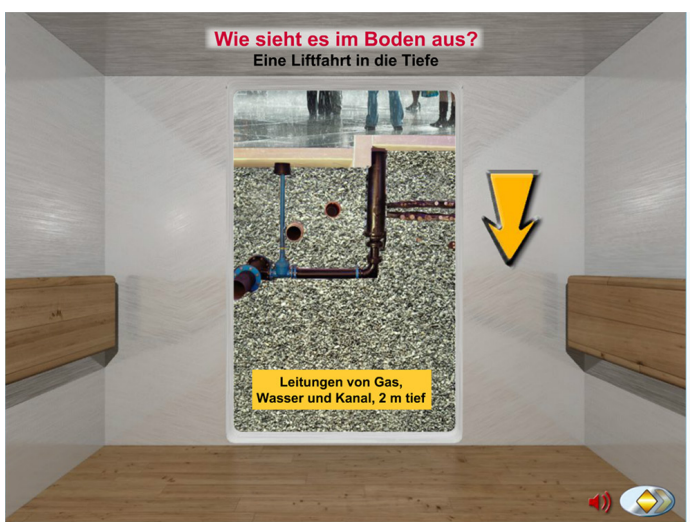

\section{Screenshot 1}

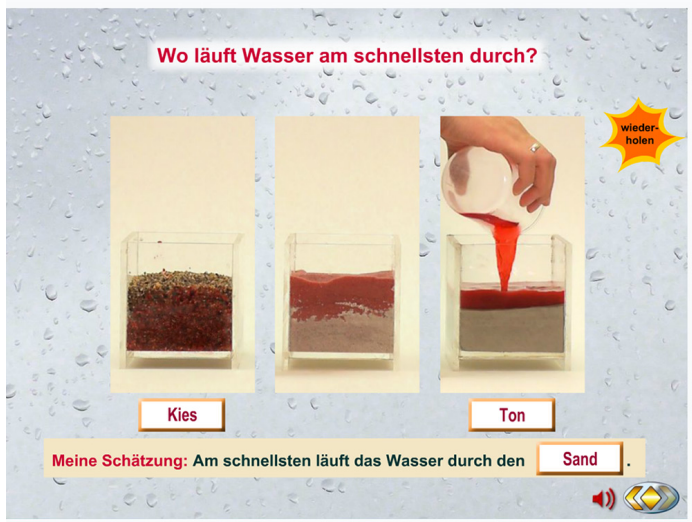

Screenshot 3

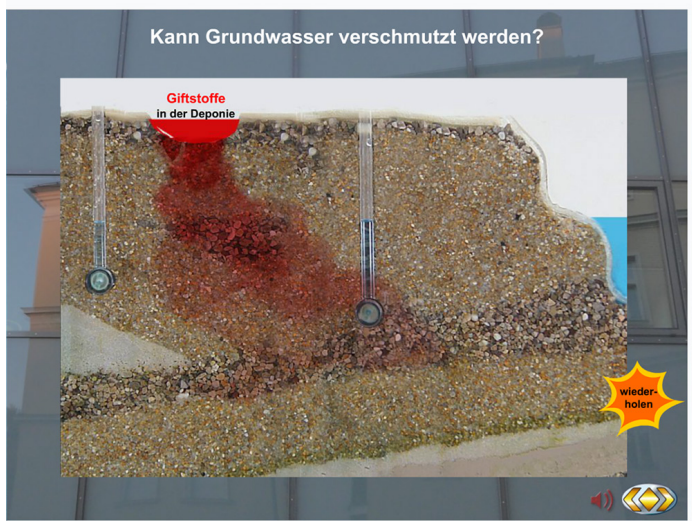

Screenshot 5

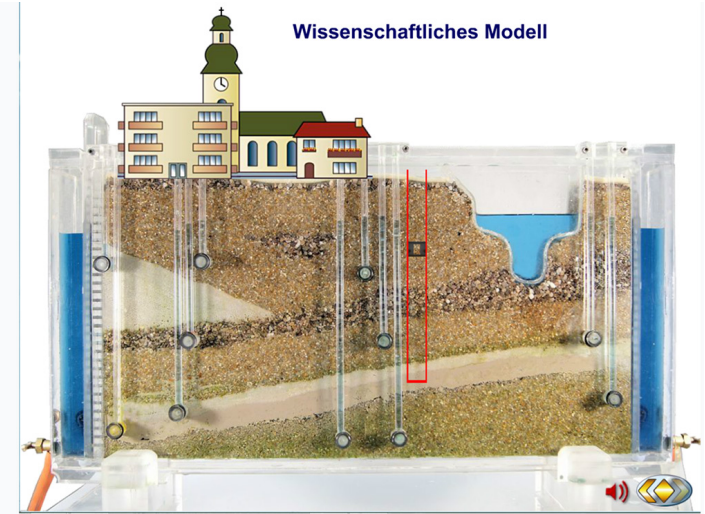

\section{Screenshot 2}

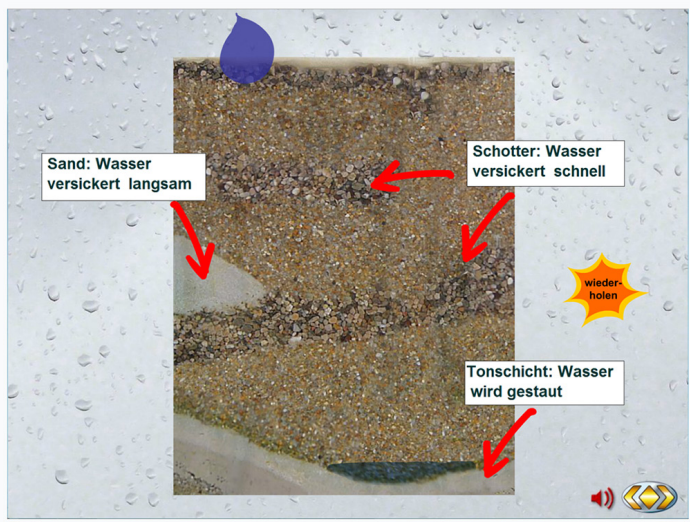

\section{Screenshot 4}

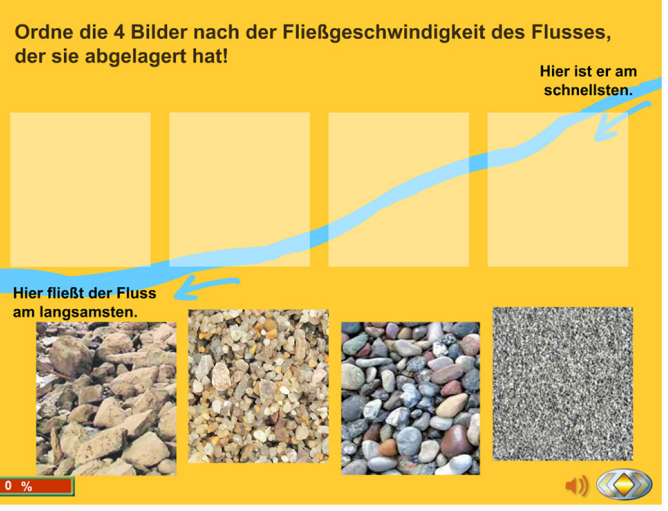

Screenshot 6

Figure 11. Screenshots from the multimedia learning program.

cant differences were observed between the experimental and control groups. The highest knowledge scores were achieved on the basic geological concepts of sediments and pore space, which were mainly dealt with during the first part of the multimedia program. In addition, pupils and students from the experimental group also performed better in the transfer task. Being able to use the knowledge gained in various everyday situations is one of the primary objectives of science education. Additionally, the participants' subjective certainty when completing the questionnaire was significantly higher in the experimental group.

In particular pupils with little or no prior knowledge about groundwater mostly improved their performance by working with the program. Similar results have been reported from other studies on the efficiency of multimedia learning programs (Unterbruner and Unterbruner, 2005; Unterbruner et al., 2008). We believe that a key factor is that (well-designed) multimedia learning programs can reduce or even avoid cognitive overload, because individual information processing 
occurs at the user's own pace and is therefore adapted to their own reading and listening competency. On the other hand, learning in class is often adjusted to the skills of an average pupil. In addition, the program's interestingness and comprehensibility were rated very highly by the participants. Especially learners with little prior knowledge benefitted from comprehensible, coherent, and well-arranged texts, pictures, and animations (cf. Mayer, 2005, 2009).

Furthermore, there is strong evidence that our multimedia program was successful in fostering the motivation for engaging with the topic of groundwater and increasing the "commitment" factor (Sinatra, 2005). In addition to the abovementioned interestingness, most of the participants really enjoyed working with the program (see Table 4). Apparently, the multimedia learning program was able to enhance motivation, a component which is argued to be a key factor in promoting conceptual change (Sinatra, 2005; Heddy and Sinatra, 2013).

Nevertheless, it is evident that the conception of groundwater as an underground river or lake is a very strong idea. Approximately half of our pupils and students proved to be resistant to the new concept of groundwater as water within porous and permeable rocks. In these cases, working with the program as a singular intervention was not sufficient. In future studies, we will examine how an incorporation of the multimedia learning program into a classroom-based learning environment might enhance its effectiveness.

The fact that there were a greater amount of unclear drawings in the post-test (see Table 3) may be interpreted as an intermediate step in the process of conceptual reconstruction. These unclear drawings can be understood as indicators for a learning process that had started by working with the program but had not been completed in the sense of conceptual reconstruction. New knowledge may have been gained but not deeply understood. As mentioned above, the program's incorporation into a classroom setting might also reduce the number of unclear drawings as a result of an intensified engagement with the topic.

Another reason for the lack of success in these cases may be the factor of user behavior. Some participants rushed through the program. Their motivation for attentively working on the program might also be stronger if the multimedia program was implemented in class.

In accordance with Schwartz et al. (2011), our data led to the conclusion that the incorporation of drawings in assessments is a meaningful tool in order to demonstrate an understanding of the conception of groundwater. The drawings frequently revealed an incorrect or vague understanding of the groundwater system, and enabled a better understanding of the participants' mental models of groundwater. Dickerson and Dawkins (2004) also found that students were able to state ideas about groundwater and the water cycle using correct terminology to describe incorrect thinking. Schwartz et al. (2011) emphasized that students' ability to conceptualize the groundwater system, as evidenced by their drawings, seems to be "a much stronger predictor of content mastery than the ability to answer objective questions" (Schwartz et al., 2011, p. 148).

Critics point out that drawing ability can be a limiting factor. Participants may, for example, leave out certain details that they are unable to draw (Dove et al., 1999). Based on our detailed analyses, we think that it is not primarily drawing ability that is a limiting factor, but rather a vague or missing conception of the topic. As many pupils' and students' drawings showed, a few lines based on a clear mental model suffice for depicting groundwater, and artistic skills are not required. Additionally, many drawings clearly showed where working with the multimedia learning program had resulted in an improved understanding of the concept of groundwater, and details in the drawings made clear where conceptual change had taken place (see Fig. 10).

In summary, the theory-based multimedia learning program presented here can improve teaching and learning of hydrogeological concepts. Our data suggest that it is a powerful tool for promoting meaningful learning about groundwater in terms of both conceptual change and improved knowledge. The tool has proved to be appropriate for pupils in class as well as students in teacher training.

\section{The Supplement related to this article is available online at doi:10.5194/hess-20-2251-2016-supplement.}

Acknowledgements. The authors would like to express their gratitude to Ecovia - Landschaft, Wasser, Bildung for their permission to use their analog groundwater model Demokoffer Grundwasser for the visualization of groundwater dynamics in our multimedia learning program and in some of the screenshots presented here. We greatly appreciate the constructive suggestions made by two anonymous reviewers.

Edited by: S. Illingworth

\section{References}

Ben-zvi-Assarf, O. and Orion, N.: A Study of Junior High Students' Perceptions of the Water Cycle, J. Geosci. Educ., 53, 366-373, 2005.

BMBF - Bundesministerium für Bildung und Frauen: Lehrpläne der AHS und Hauptschule (HS, NMS), Wien, https://www.bmbf. gv.at/schulen/unterricht/lp (last access: 26 August 2014), 2000.

Chan, C., Burtis, J., and Bereiter, C.: Knowledge building as a mediator of conflict in conceptual change, Cognit. Instruct., 15, 1-40, 1997.

Cheek, K. A.: A Summary and Analysis of Twenty-Seven Years of Geoscience Conception Research, J. Geosci. Educ., 58, 122-134, 2010.

Davis, N. S. and de Wiest, R. J. M.: Hydrogeology, Elsevier, Amsterdam, 463 pp., 1966. 
Dickerson, D. and Dawkins, K.: Eighth Grade Students' Understanding of Groundwater, J. Geosci. Educ., 52, 178-181, 2004.

Dickerson, D., Callahan, T. J., Sickle, M. V., and Hay, G.: Students' Conceptions of Scale Regarding Groundwater, J. Geosci. Educ., 53, 374-380, 2005.

Dickerson, D. L., Penick, J. E., Dawkins, K. R., and Sickle, M. V.: Groundwater in Science Education, J. Sci. Teacher Educ., 18, 45-61, 2007.

Dove, J. E., Everett, L. A., and Preece, P. F. W.: Exploring a hydrological concept through children's drawings, Int. J. Sci. Educ., 21, 485-497, doi:10.1080/095006999290534, 1999.

Duffy, D.: The nature and role of physical models in enhancing sixth grade studentents' mental models of groundwater and groundwater processes, Graduate Thesis, Old Dominion University, Norfolk, VA, 137 pp., 2012.

Duit, R.: Science education research internationally: Conceptions, research methods, domains of research, Eurasia J. Math. Sci. Technol. Educ., 3, 3-15, 2007.

Duit, R. and Treagust, D. F.: Conceptual change: A powerful framework for improving science teaching and learning, Int. J. Sci. Educ., 25, 671-688, 2003.

Duit, R., Gropengießer, H., Kattmann, U., Kormorek, M., and Parchmann, I.: The model of educational reconstruction - a framework for improving teaching and learning science, in: Science Education Research and Practice in Europe: Retrospective and Prospective, edited by: Jorde, D. and Dillon, J., Sense Publishers, Rotterdam, 13-37, 2012.

Fleiss, J. L. and Cohen, J.: The equivalence of weighted kappa and the intraclass correlation coefficient as measures of reliability, Educ. Psychol. Measure., 33, 613-619, 1973.

Hammann, M. and Asshoff, R.: Schülervorstellungen im Biologieunterricht: Ursachen für Lernschwierigkeiten, Klett Verlag, Seelze, 309 pp., 2014.

Heddy, B. C. and Sinatra, G. M.: Transforming Misconceptions: Using Transformative Experience to Promote Positive Affect and Conceptual Change in Students Learning About Biological Evolution, Sci. Educ., 97, 723-744, 2013.

Hilberg, S.: Einführung in die Umweltgeologie, Springer Verlag, Berlin, Heidelberg, 245 pp., 2015.

Hölting, B. and Coldewey, W. G.: Hydrogeologie, 8th Edn., Springer Spektrum, Stuttgart, Heidelberg, 438 pp., 2013.

Kattmann, U.: Lernen mit anthropomorphen Vorstellungen? Ergebnisse von Untersuchungen zur Didaktischen Rekonstruktion in der Biologie, Z. Didakt. Naturwiss., 11, 165-174, 2005.

Kattmann, U.: Schüler besser verstehen. Alltagsvorstellungen im Biologieunterricht, Aulis-Verlag, Köln, 416 pp., 2015.

Kattmann, U., Duit, R., Gropengießer, H., and Komorek, M.: Das Modell der Didaktischen Rekonstruktion. Ein Rahmen für naturwissenschaftliche Forschung und Entwicklung, Z. Didakt. Naturwiss., 3, 3-18, 1997.

Lakoff, G. and Johnson, M.: Metaphors we live by, The Chicago University Press, Chicago, London, 276 pp., 2003.

Langer, I., Schultz von Thun, F., and Tausch, R.: Sich verständlich ausdrücken, Ernst Reinhardt Verlag, München, Basel, 222 pp., 2011.

Limón, M.: On the cognitive conflict as an instructional strategy for conceptual change: a critical appraisal, Learn. Instruct., 11, 357380,2001
Mayer, R. E. (Ed.): Principles of Multimedia Learning Based on Social Cues: Personalization, Voice, and Image Principles, in: The Cambridge Handbook of Multimedia Learning, Cambridge University Press, Cambridge, 201-212, 2005.

Mayer, R. E.: Multimedia Learning, Cambridge University Press, New York, 210 pp., 2009.

Mayer, R. E. and Moreno, R.: Nine Ways to Reduce Cognitive Load in Multimedia Learning, Educ. Psychol., 38, 43-52, 2003.

Moreno, R.: Does the modality principle hold for different media? A test of the method-affects-learning hypothesis, J. Comput. Assist. Learn., 22, 149-158, 2006.

Reinfried, S.: Wie kommt Grundwasser in der Natur vor? Ein Beitrag zur Praxisforschung über physisch-geographische Alltagsvorstellungen von Studierenden, Geogr. Didakt., 33, 133156, 2005.

Reinfried, S.: Conceptual Change in Physical Geography and Environmental Sciences through Mental Model Building: The Example of Groundwater, Int. Res. Geogr. Environ. Educ., 15, 41-61, 2006a.

Reinfried, S.: Alltagsvorstellungen - und wie man sie verändern kann, Geographie Heute, 243, 38-43, 2006b.

Reinfried, S., Mathis, C., and Kattmann, U.: Das Modell der Didaktischen Rekonstruktion - eine innovative Methode zur fachdidaktischen Erforschung und Entwicklung von Unterricht, Beitr. Lehrerbild., 27, 404-414, 2009.

Reinfried, S., Tempelmann, S., and Aeschbacher, U.: Addressing secondary school students' everyday ideas about freshwater springs in order to develop an instructional tool to promote conceptual reconstruction, Hydrol. Earth Syst. Sci., 16, 1365-1377, doi:10.5194/hess-16-1365-2012, 2012.

Schultz, J. W.: Student conceptions of groundwater, Graduate Thesis, Faculty of the Graduate School of the University of Minnesota, ProQuest Dissertations Publishing, 216 pp., 2006.

Schwartz, K. L., Thomas-Hilburn, H., and Haverland, A.: Grounding Water: Building Conceptual Understanding through Multimodal Assessment, J. Geosci. Educ., 59, 139-150, 2011.

Seibert, J., Uhlenbrook, S., and Wagener, T.: Preface "Hydrology education in a changing world", Hydrol. Earth Syst. Sci., 17, 1393-1399, doi:10.5194/hess-17-1393-2013, 2013.

Shepardson, D. P., Wee, B., Priddy, M., Schellenberger, L., and Harbor, J.: Water Transformation and Storage in the Mountains and at the Coast. Midwest students' disconnected conceptions of the hydrologic cycle, Int. J. Sci. Educ., 31, 1447-1471, 2009.

Sinatra, G. M.: The "Warming Trend" in Conceptual Change Research: The Legacy of Paul R. Pintrich, Educ. Psychol., 40, 107115, doi:10.1207/s15326985ep4002_5, 2005.

Sinatra, G. M. and Pintrich, P. R.: Intentional conceptual change, Lawrence Erlbaum Associates, Inc., Mahwah, NJ, 496 pp., 2003.

Strike, K. A. and Posner, G. J.: A revisionist theory of conceptual change, in: Philosophy of science, cognitive psychology, and educational theory and practice, edited by: Duschl, R. A. and Hamilton, R. J., State University of New York Press, New York, 147-176, 1992.

Suter, D., Küry, D., Baltes, B., Nagel, P., and Leimgruber, W.: Kulturelle und soziale Hintergründe zu den Wahrnehmungsweisen von Wasserquellen, Mitteil. Naturforsch. Gesell. Basel, 10, 81$100,2007$. 
Thompson, S. E., Ngambeki, I., Troch, P. A., Sivapalan, M., and Evangelou, D.: Incorporating student-centered approaches into catchment hydrology teaching: a review and synthesis, Hydrol. Earth Syst. Sci., 16, 3263-3278, doi:10.5194/hess-16-32632012, 2012.

Unterbruner, U. and Hilberg, S.: Zwischen Regenwolke und Wasserhahn (Between the raincloud and the tap), CD-ROM and online programm, University of Salzburg, http://www. multimedialernen.at, last access: 19 May 2016, 2012.

Unterbruner, U. and Pfligersdorffer, G.: Problembasiertes Lernen im Biologieunterricht, in: Problembasiertes Lernen, edited by: Zumbach, J., Weber, A., and Olsowksi, G., Konzepte, Werkzeuge und Fallbeispiele aus dem deutschsprachigen Raum, h.e.p. Verlag, Bern, 117-130, 2007.

Unterbruner, U. and Unterbruner, G.: Multimedialernen im Ökologieunterricht: Lernprozesse und Programmgestaltung, in: Lehrund Lernforschung in der Biologiedidaktik, Band 1, edited by: Klee, R. and Bayrhuber, H., Studienverlag, Innsbruck, 187-198, 2002.

Unterbruner, U. and Unterbruner, G.: Wirkung verarbeitungsfördernder multimedialer Programmgestaltung auf den Lernprozess von 10- bis 12-Jährige, in: Lehr- und Lernforschung in der Biologiedidaktik, Band 2, edited by: Klee, R., Sandmann, A., and Vogt, H., Studienverlag, Innsbruck, 181-194, 2005.
Unterbruner, U., Pfligersdorffer, G., and Zumbach, J.: natureLe@ rn - eine Studie zum problemorientierten Ökologieunterricht via Lernplattform 'moodle', in: Lehr- und Lernforschung in der Biologiedidaktik, Band 3, edited by: Sandmann, A. and Harms, U., Studienverlag, Innsbruck, 199-215, 2008.

Vosniadou, S.: The Cognitive-Situative Divide and the Problem of Conceptual Change, Educ. Psychol., 42, 55-66, 2007.

Vosniadou, S.: International Handbook of Research on Conceptual Change, Routledge, New York, 643 pp., 2013.

Vosniadou, S.: Examining cognitive development from a conceptual change point of view: The framework theory approach, Eur. J. Dev. Psychol., 11, 645-661, 2014.

Wampler, J. M.: Problematic Descriptions of Ground-Water Movement, J. Geosci. Educ., 46, 282-284, 1998.

Wampler, J. M.: Misconceptions of the Development of Cones of Depression, J. Geosci. Educ., 48, 239-241, 2000.

White, R. and Gunstone, R.: Probing understanding, The Falmer Press, London, 196 pp., 1992.

Zumbach, J., Moser, S., Unterbruner, U., and Pfligersdorffer, G.: Problemorientiertes Online-Lernen im Biologieunterricht: Fähigkeitsselbstkonzept, mentale Anstrengung und Vorwissen als Prädiktoren für Wissenserwerbsprozesse zwischen Instruktion und Konstruktion, Z. Didakt. Naturwiss., 20, 45-56, doi:10.1007/s40573-014-0004-6, 2014. 